\title{
CHANGES IN PHYSICAL FITNESS OF MEN OLDER THAN 60 YEARS - A PILOT STUDY
}

\author{
Zoran Milanović ${ }^{1}$, Saša Pantelić ${ }^{1}$, and Bojan Jorgić ${ }^{1}$ \\ ${ }^{1}$ Faculty of Sport and Physical Education, University of Nis, Serbia
}

\section{SUMMARY}

The aim of this study was to determine the differences in physical fitness in men older than 60 . Two hundred and seventy-two subjects were included in this study. All subjects were divided into five age categories, as follows: 90 subjects aged 60-64 (33\%), 70 subjects aged 65-69 (26\%), 50 subjects aged $70-74(18 \%) 41$ subjects aged $75-79(15 \%)$ and 21 subjects over the age of $80(8 \%)$. All subjects performed a battery of tests called the senior fitness test. The test consists of six measures of physical fitness: 1) Back scratch, 2) Chair sit and reach, 3) 8 foot up and go, 4) 30 sec stand from the chair, 5) Arm curl, 6) 2-minutes step test. Results of body mass index showed that all subjects were overweight regardless of age category. There is no statistically significant difference $(p>.05)$ in flexibility between subjects of different age groups after the age of 60 . The greatest differences were found in lower and upper extremities strength. The subjects aged 60-64 significantly differ in the strength of the lower extremities $(p<.05)$ compared to subjects aged $70-74$ and $75-79$ years of age. The greatest heterogeneity was found in the parameters of aerobic endurance, with values progressively decreasing from the age of $60(78.60 \pm 42.00)$ to $80(73.68 \pm 35.62)$. It could be concluded that there was increase of fat tissue, with reduced level of muscle activity. In addition, it could be stated that aging process decrease muscle strength and endurance in elderly people.

Key Words: fitness, senior fitness test, elderly aging.

\section{INTRODUCTION}

Anthropometric, fitness and functional characteristics are closely associated with lifestyle, health and functional status of elderly persons (Perissinotto, Pisent, Sergi, \& Grigoletto, 2002). Therefore, it is very difficult to give a standard interpretation of their values. The process of aging brings a lot of physiological and nutritional changes such as reduced body weight and body height (Milanovic, Pantelic, Trajkovic, \& Sporiš, 2011). It is well known that overweight and obesity are closely associated with increased risk of cardiovascular disease, chronical disease, and reduced range of motion (Musta et al., 1999).

Longitudinal studies (Visser et al., 2003) has showed that body weight has decreased in elderly men and women after 60 years of age. In additional Sánche García et al. (2007) has stated that body weight significantly differs between men and women (70.3 vs.
$62.7 \mathrm{~kg})$, as well as height (163 vs. $152 \mathrm{~cm})$. This findings are supported by other studies (Reddy \& Rao, 2010; Setiati et al., 2010). It is considered that after 75 years, BMI and anthropometric measures are significantly decresing in men and women.

Despite these anthropometric changes, the level of functional fitness is often used as a parameter for monitoring and evaluation of public health and almost always associated with health status. Rikli and Jones (2001) have defined functional fitness as the physical capacity to perform daily activities independently and without the appearance of fatigue. This monitoring is especially important for elderly people above 60 years for preventing many diseases, occurrence of immobilization and reduction of mortality rates. Neverthless, physical activity affects the occurrence of storage diseases and immobilization while at the same time raise the functional capabilities that can be maintained even after exercising (Toraman, Ayceman, \& Yaman, 2005). 
However, there are many barriers for the inclusion of elderly persons in the process of physical activity regardless of the nature of the exercise. Gender is one of the most important factors for elderly persons and their participation in sports and recreational activities (Trost, Owen, Bauman, Sallis, \& Brown, 2002). It was found that women have lower level of participating in sports and recreational activities than men aged over 60> (Leslie, Fotheringham, Owen, \& Bauman, 2001). Moschny, Platen, Klaaben-Mielke, Trampisch and Hinrichs (2011) concluded in their study that men are more engaged in sport activities than women (01:45 vs. 01:10 hours per week) while women spend more time per week in household work (04:00 vs. 03:00 h).

Separate analysis of different activities should provide deeper understanding of participation in various activities. But according to the author's kno- wledge, existing studies have focused on examining the potential forms of physical activity in older persons who are solely focused on one type of activity, examing only men or only women, or showing the results of all activities (Ashe, Miller, Eng, \& Noreau, 2008; Chad et al., 2005; Haley \& Andel, 2010; Kaplan, Newsom, McFarland, \& Lu, 2001; Lawlor, Taylor, Bedford, \& Ebrahim, 2002; Ruchlin \& Lachs, 1999; Walsh, Pressman, Cauley, \& Browner, 2001).

It was hypothesized that aging brings certain changes in anthropometric and fitness parameters of men older than 60 . Therefore, the primary objective of this study was to determine differences in the field of functional fitness in men older than 60 which were divided into five age categories. A secondary objective was to determine which of the five age categories $(60-64,65-69,70-74,75-79$ and over 80 years) carries the greatest changes.

\section{TABLE 1}

General descriptive parameters $(M \pm S D)$.

\begin{tabular}{ccccc}
\hline $\begin{array}{c}\text { Age } \\
\text { category }\end{array}$ & $n(\%)$ & $\begin{array}{c}\text { Body Height } \\
(\mathrm{cm})\end{array}$ & $\begin{array}{c}\text { Body Weight } \\
(\mathrm{kg})\end{array}$ & $\begin{array}{c}\text { BMI } \\
\left(\mathrm{kg} / \mathrm{m}^{2}\right)\end{array}$ \\
\hline $60-64$ & $90(33 \%)$ & $178.19 \pm 6.65$ & $80.88 \pm 9.59$ & $25.50 \pm 3.02$ \\
\hline $65-69$ & $70(26 \%)$ & $177.00 \pm 9.35$ & $84.54 \pm 13.81$ & $27.03 \pm 4.15$ \\
\hline $70-74$ & $50(18 \%)$ & $174.50 \pm 7.71$ & $79.78 \pm 11.69$ & $26.27 \pm 4.00$ \\
\hline $75-79$ & $41(15 \%)$ & $175.34 \pm 7.79$ & $78.27 \pm 13.13$ & $25.39 \pm 3.67$ \\
\hline $80>$ & $21(8 \%)$ & $176.43 \pm 8.95$ & $78.48 \pm 10.44$ & $25.25 \pm 3.20$ \\
\hline Total & 272 & $176.64 \pm 8.02$ & $81.04 \pm 11.93$ & $26.00 \pm 3.68$ \\
\hline
\end{tabular}

Legend: $\boldsymbol{n}$ - Number of respondents; $B M I$ - Body mass index; $M$ - Sample mean; $S D$ - Standard deviation.

\section{METHODS}

\section{Subjects}

Two hundred and seventy-two subjects were included in this study. All subjects were divided into five age categories, as follows: 90 subjects aged 60-64 $(33 \%), 70$ subjects aged $65-69(26 \%), 50$ subjects aged $70-74(18 \%) 41$ subjects aged $75-79(15 \%)$ and 21 subjects over the age of $80(8 \%)$. General descriptive parameters are present in Table 1 . The age of participants ranged from 60-91 years. All the participants provided written consent after being informed of the test protocol. The protocol of the study was approved by the Ethical Committee of the Faculty of sport and physical education, University of Nis and according to the revised Declaration of Helsinki. All subjects were first informed of the possible consequences of testing as well as the benefits of the research revealed their age population. Testing of all patients was in the period from October to December of 2011. Criteria for selecting participants were: age between 60 and 80 years, physically independent person - able to walk 20 feet without assistance or rest, lack of cognitive impairment and dementia, achieved 24 points for the educated and 18 points for the unqualified subjects in mini mental state evaluation (McDowell \& Newell, 1996). Participants who were in the recovery phase of an acute illness, then the deaf and blind were excluded. The research does not include subjects with cardiovascular system disorders because of the potential risks during the functional fitness tests.

All patients were mentally and physically able to participate in the study. People trained for this survey first conducted standard interviews with potential 
subjects individually or in small groups, at their homes or in the active centers for the elderly. Each participant gave his/her demographic characteristics and then approach to the testing of anthropometric measures and the Senior Fitness Test (SFT).

\section{Antrhropometric measures}

Body height and body weight were measured according to the instructions of the International Biological Program-IBP (Weiner \& Lourie, 1969). The body height was measured with a GPM anthropometer (Siber \& Hegner, Zurich, Switzerland) to the nearest $0.1 \mathrm{~cm}$. Body weight was obtained by TANITA BC 540 (TANITA Corp., Arlington Heights, IL) to the nearest $0.1 \mathrm{~kg}$. Body mass index was calculated by formula: BMI = body weight $(\mathrm{kg}) /\left(\right.$ body height $\left(\mathrm{m}^{2}\right)$.

\section{Senior fitness test}

Senior fitness test is a battery of tests for the assessment of the functional fitness of older persons. This test assesses the physiological capacity for carrying out normal daily activities independently and safely without the appearance of fatigue. Before testing, the subjects have performed 10 minutes warm up with the instructions given by highly skilled persons, and then a complete SFT with the tasks order referred in this test (Rikli \& Jones, 2001). This test has validity by Rikli and Jones (1999). The test consists of six measures of functional fitness: 1) Back scratch, 2) Chair sit and reach, 3) 8-foot up and go 4) Chair stand up for $30 \mathrm{sec}$, 5) Arm curl, 6) 2-minutes step test. Back scratch is the test for the assessment of upper body (shoulder) flexibility. Each subject is performing two test trials and then two attempts which are measured and included for further analysis. The result is the shortest distance between extended middle fingers. Chair sit and reach is a test for the assessment of lower extremities flexibility. As with the previous test, each subject is performing two test trials and two attempts to be measured and included in further analysis. The result is the longest distance between extended fingers and tip of toes. 8-foot up and go assess agility/dynamic balance. Each subject is performing one test trial and two attempts to be measured and included in further analysis. The result is the shortest time in seconds required from subject to get up from a seated position, walk 8 feet, turn, and return to seated position. Chair stand up for $30 \mathrm{sec}$ is the test for the assessment of lower body strength. Each subject has two test trials after which the protocol of measurement occurs where subject has to perform maximal number of full stands in 30 seconds. Arm curl is the test for the assessment of upper body strength. Each subject has two test trials and then the test is finished after 30 seconds. The result is the number of bicep curls in full range of motion that can be completed in 30 seconds. 2 -minutes step test is muscle endurance test. The subject, turned against the wall, has to perform maximal number of full steps with requested hight in 2 minutes. The test is performed only once and subject doesn't run but walk as fast as he can.

\section{Statystical analysis}

The statistical Package for Social Studies SPSS (v17.0., SPSS Inc., Chicago, IL) was used for statistical analysis. Descriptive statistics were reported as mean $\pm S D$ for all measures. To determine the differences between age groups we used univariate analysis of variance (ANOVA). We used Bonferroni correction to determine which of groups are statisticaly different. The statistical significance was set at $p<$ .05 .

\section{RESULTS}

The largest number of subjects were in the age category of 60-64 (33\%). With the increase of age, the number of subjects reduces so that in the category over the age of 80 was only $8 \%$ of subjects. Body height was quite similar between groups and ranged from $178.19 \pm 6.65 \mathrm{~cm}$ in subjects $60-64$ years of age to $174.50 \pm 7.71 \mathrm{~cm}$ in subjects 10 years older ( $70-74$ years of age). Also statistically significant difference was found for body weight $(p<.05)$. Results of body mass index showed that all subjects were overweight regardless to the age category (Table 1). The highest values of BMI were recorded in men aged $65-69\left(\mathrm{BMI}=27.03 \pm 4.15 \mathrm{~kg} / \mathrm{m}^{2}\right)$ and the lowest in the oldest subjects, over the age of 80 (25.25 $\pm 3.20 \mathrm{~kg} / \mathrm{m}^{2}$ ).

Table 2 shows that there is no statistically significant difference in flexibility between subjects of different age groups after the age of 60 . Also, results for agility and dynamic balance ( 8 foot up and go test) have showed that there is no statistical difference between groups. The greatest differences were found in lower and upper extremities strength. The subjects aged 60-64 significantly differ in the strength of the lower extremities $(\not<.05)$ compared to subjects aged 70-74 and 75-79. Upper limbs strength significantly differes between subjects aged 60-64 and $70-74$ (18.16 \pm 4.87 vs $16.37 \pm 5.90$ repetitions). The greatest heterogeneity was found in the parameters of aerobic endurance, with values progressively decreasing from the age of $60(78.60 \pm 42.00)$ to $80(73.68$ \pm 35.62 ). 


\section{TABLE 2}

Senior fitness test according to age category $(M \pm S D)$.

TABELA 2

Parametri senior fitness testa po starosnim kategorijama $(M \pm S D)$

\begin{tabular}{lccccc}
\hline & \multicolumn{5}{c}{ Male } \\
\cline { 2 - 6 } & $60-64$ & $65-69$ & $70-74$ & $75-79$ & $80>$ \\
\hline Back scratch $(\mathrm{cm})$ & $-6.45 \pm 8.90$ & $-9.03 \pm 9.23$ & $-9.85 \pm 12.78$ & $-7.98 \pm 11.61$ & $-10.74 \pm 11.50$ \\
\hline Seat and reach (cm) & $.11 \pm 6.87$ & $-.60 \pm 10.53$ & $4.05 \pm 9.43$ & $1.38 \pm 8.24$ & $.73 \pm 9.00$ \\
\hline 8 foot up and go (sec) & $7.52 \pm 6.54$ & $8.10 \pm 2.91$ & $9.84 \pm 8.88$ & $7.84 \pm 3.34$ & $7.97 \pm 3.34$ \\
\hline 30 sec stands from chair (rep) & $15.34 \pm 4.32^{\Omega \#}$ & $13.90 \pm 5.87$ & $14.45 \pm 5.05^{\Omega}$ & $12.43 \pm 5.24^{\#}$ & $12.74 \pm 5.10$ \\
\hline Arm curle (rep) & $18.16 \pm 4.87^{\Omega}$ & $16.54 \pm 6.19$ & $16.37 \pm 5.90^{\Omega}$ & $16.76 \pm 7.08$ & $16.79 \pm 5.11$ \\
\hline 2 - minute step test (rep) & $78.60 \pm 42.90^{\Omega \#}$ & $75.64 \pm 57.80^{\ddagger}$ & $67.44 \pm 33.92^{\Omega}$ & $55.46 \pm 40.97^{\# \ddagger}$ & $73.68 \pm 35.62$ \\
\hline
\end{tabular}

Legend: * - Statistically significant difference between age $65-69$ and $70-74 ;$; - Statistically significant difference between age 65-69 and $80>;^{\dagger}$ - Statistically significant difference between age 60-64 and 65-69; ₹- Statistically significant difference between age 65-69 and 75-79; ${ }^{\Omega}$ - Statistically significant difference between age $60-64$ and 70-74; " - Statistically significant difference between age 60-64 and 75-79; rep - Repetition.

\section{DISCUSSION}

Promoting a healthy lifestyle of the elderly has become more important due to the dramatic increase in population over the last two decades. The level of physical activity is often used as a parameter for monitoring and evaluation of public health. This monitoring is especially important for the elderly to prevent many diseases, occurrence of immobilization and reduction of mortality rate (Milanovic et al., 2011).

The average height and weight of the participants was $176.64 \pm 8.02 \mathrm{~cm}, 81.04 \pm 11.93 \mathrm{~kg}$ respectively, which was greater than the results shown in the study Velazguez Alva et al. (1996) who recorded the average value for men of the same age $163.8 \pm 5.53 \mathrm{~cm}$, $70.07 \pm 9.92 \mathrm{~kg}$, as indicated by other studies (Cicioglu, 2010; Sánchez García et al., 2007; Setiati et al., 2010). The results of our study are similar with study Guo, Zeller, Chumlea, and Siervogel (1990), who found that the total weight increases from the age of 60 to 70 . However, in the study Visser et al. (2003) body weight increses after the age of 60 which is contrary to our results. The values of BMI show that subjects in our study are overweight (BMI > 25), which could lead to the emergence of various chronic diseases and reducing capacity (Pai, 2011; Perissinotto et al., 2002). Obesity is one of the most occurent public health problems which can be effectively prevented (Milanovic et al., 2011). Perissinoto et al.
(2002) found lower BMI values between the ages of 65-75 than in the period between $75-80$, which is contrary with our results. The results of our study have confirmed the trend of incresed obesity among elderly people in the last two decades (Misra \& Khurana, 2008). Aging is associated with a higher percentage of body fat and body fat redistribution. Distribution of lower-body subcutaneous adipose tissue in the abdominal and visceral part is the most common with the elderly people. The reduction in BMI occurs due to the loss of muscle mass and increase of fat tissue in waist and hips.

Given that this study has only analyzed BMI parameter, a clearer picture of the redistribution of body fat is necessary for a future study. In our study, decrease in muscle strength of upper and lower extremities with progressive increase in the number of years is noticeable. Decrease in muscle strength during the aging process is the result of significant loss of muscle mass, which may cause the decrease in physical activity (Радовановић \& Игњатовић, 2009) but also increase the risk of falls and injuries in older people. Sedentary lifestyle has significant impact on muscle mass and increases subcutaneous adipose tissue. The results of this study clearly show that men are less physically active with aging proces which could be reflected on their muscular strength and endurance. Our study has shows statistically significant decrease of aerobic endurance in subjects 
aged 60-64 and those older than 75. Thus, the reduction of muscle function should be attributed to a combination of factors such as aging and physical inactivity (Shephard, 1997; Spirdusso, 1995). This could be confirmed by Jozsi, Campbell, Joseph, Davey, and Evans (1999), and Toraman et al. (2005) who found that appropriate level of training can maintain muscle strength and endurance. Another reason for decrease in muscle strength and endurance is to reduce the number of muscle fibers during the aging process. The results show that approximately $10 \%$ of muscle fibers are lost during each decade after the age of 50 (Lexell, Taylor, \& Sjöström, 1988). On the other side, the aging process leads to reduction in activation of motor units (Радовановић \& Игњатовић, 2009).

It could be concluded that there was increase of fat tissue, with reduced level of muscle activity. In

FIGURE 1

Changes in physical fitness in relation to age.
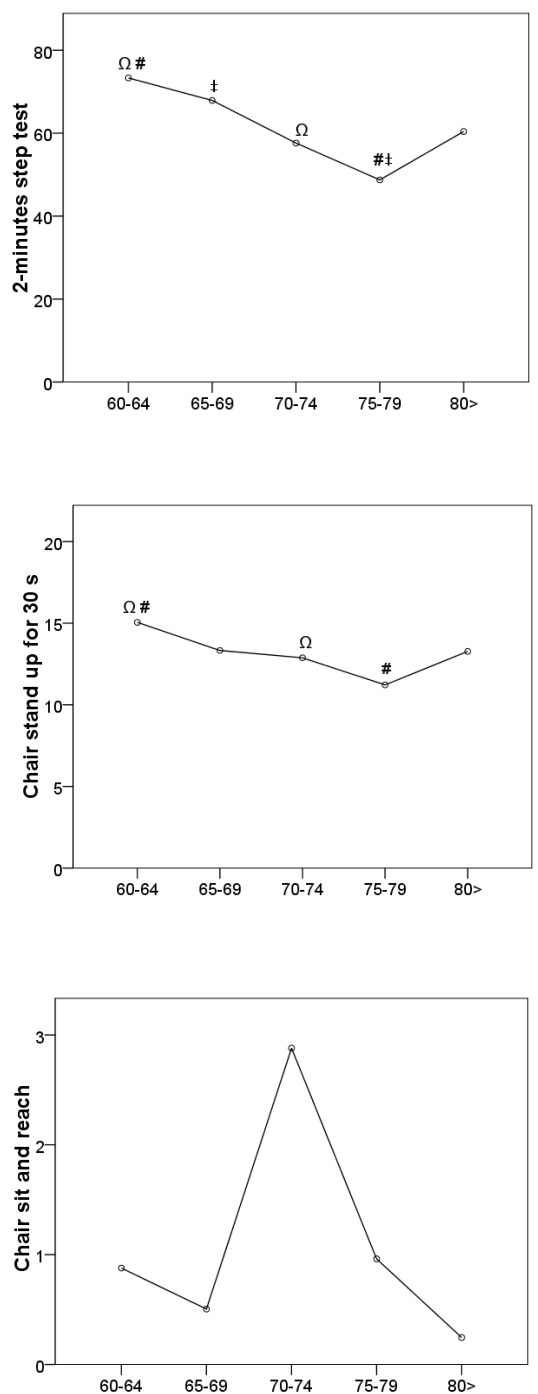

addition, it could be stated that aging process decrease muscle strength and endurance in elderly people. These parameters could lead to a greater risk of cardiovascular and respiratory diseases. Thus their work ability and physical fitness are many times reduced. Negative factors should be eliminated in order to prevent obesity and thus the above mentioned deseases. Reducing body fat could lead to better physical fitness and working capacity. Regular physical activity and functional fitness could slow down the aging process.

\section{ACKNOWLEDGEMENT}

This research was carried out as part of the project financed by the Ministry of Science of the Republic of Serbia, entitled »Physical activity and the fitness component of the elderly« (number 179056), appro-
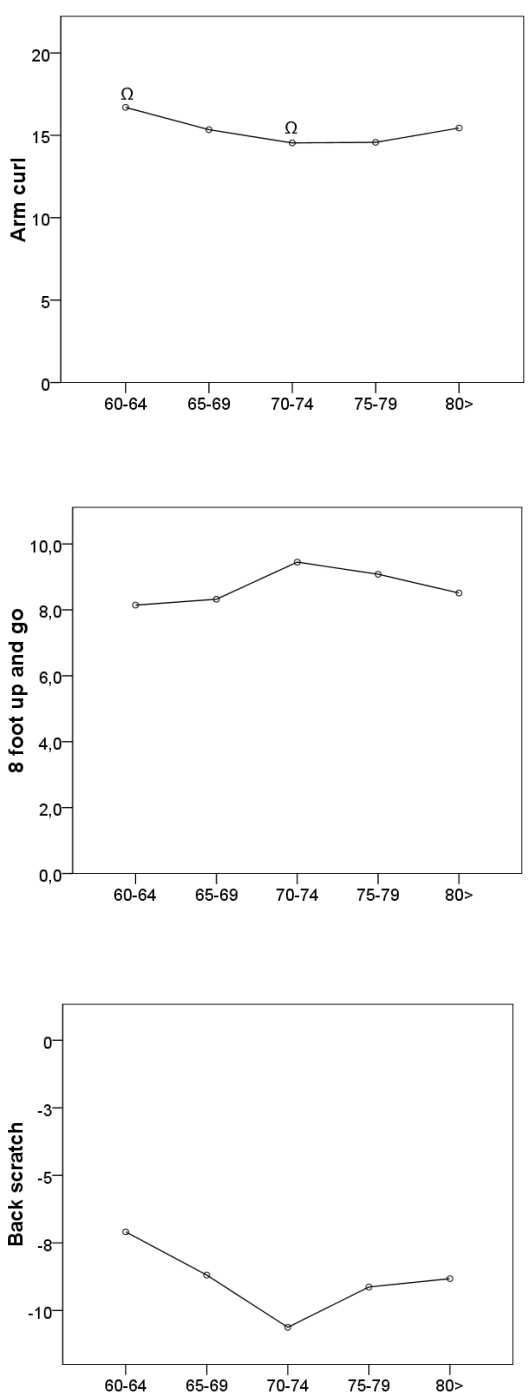
ved in 2010, and conducted by the Faculty of Sports and Physical Education of the University of Nis.

\section{REFERENCES}

Ashe, M. C., Miller, W. C., Eng, J. J., \& Noreau, L. (2008). Older Adults, Chronic Disease and Leisure-Time Physical Activity. Gerontology, 55, 64-72. doi: 10.1159/000141518; PMid: 18566534; PMCid: 3167824

Chad, K. E., Reeder, B. A., Harrison, E. L., Ashworth, N. L., Sheppard, S. M., Schultz, S. L. ... Lawson, J. A. (2005). Profile of physical activity levels in community-dwelling older adults. Medicine and Science in Sport and Exercises, 37, 1774-1784. doi: 10.1249/01. mss.0000181303.51937.9c

Cicioglu, I. (2010). Assessment of Physical Fitness Levels of Elderly Turkish Males over 60 Years. Collegium Antropologicum, 34(4), 1323-1327. PMid: 21874716

Garcia, S. S., Perla, G. C., Lopez, D. M., Cedillo, H. T., Nunez, C. A. R., \& Beamen, R. S. (2007). Anthropometric measures and nutritional status in helathy elderly population. BMC Public Helath, 7, 2-15. doi: 10.1186/1471-2458-7-2; PMid: 17201919; PMCid: 1769489.

Guo, S. S., Zeller, C., Chumlea, W. C., \& Siervogel, R. M. (1999). Aging, body composition, and lifestyle, the Fels Longitudinal Study. American Journal of Clinical Nutrition, 70(3), 405-411. PMid: 10479203

Haley, C., \& Andel, R. (2010). Correlates of Physical Activity Participation in CommunityDwelling Older Adults. Journal of Aging and Physical Activity, 18, 375-389. PMid: 20956840

Jozsi, A. C., Campbell, W. W., Joseph, L., Davey, S. L., \& Evans, W. J. (1999). Changes in power with resistance training in older and younger men and women. The journals of gerontology Series A Biological sciences and medical sciences, 54(11), M591-M596. doi: 10.1093/gerona/54.11.M591

Kaplan, M. S., Newsom, J. T., McFarland, B. H., \& Lu, L. N. (2001). Demographic and psychosocial correlates of physical activity in late life. American Journal of Preventive Medicine, 21, 306-312. doi: 10.1016/S0749-3797(01)00364-6

Lawlor, D. A., Taylor, M., Bedford, C., \& Ebrahim, S. (2002). Is housework good for health? Levels of physical activity and factors associated with activity in elderly women. Results from the British Women's Heart and Health Study. Journal of Epidemiology \& Community Health, 56, 473-478. doi: 10.1136/jech.56.6.473
Leslie, E., Fotheringham, M. J., Owen, N., \& Bauman, A. (2001). Age-related differences in physical activity levels of young adults. Medicine \& Science in Sports \& Exercise, 33, 255-258. doi: 10.1097/00005768-200102000-00014; PMid:11224815

Lexell, J., Taylor, C. C., \& Sjöström, M. (1988). What is the cause of the ageing atrophy? Total number, size and proportion of different fiber types studied in whole vastus lateralis muscle from 15- to 83-year-old men. Journal of the Neurological Sciences, 84(2-3), 275-294. doi: 10.1016/0022-510X(88)90132-3

McDowell, I., \& Newell, C. (1996). Mental status testing Measuring health: a guide to rating scales and questionnaire. New York: Oxford University Press.

Milanović, Z., Pantelić, S., Trajković, N., \& Sporiš, G. (2011). Basic anthropometric and body composition characteristics in elderly population: A Systematic Review. Facta Universitatis: Series Physical Education and Sport, 9(2), 173-182.

Misra, A., \& Khurana, L. (2008). Obesity and the metabolic syndrome in developing countries. The Journal of Clinical Endocrinology \& Metabolism, 93, S9-S30. doi: 10.1210/jc.2008-1595

Moschny, A., Platen, P., Klaaben-Mielke, R., Trampisch, U., \& Hinrichs, T. (2011). Physical activity patterns in older men and women in Germany: a cross-sectional study. BMC Public Health, 11(1), 559-572. doi: 10.1186/14712458-11-559; PMid: 21752288; PMCid: 3154867

Musta, A., Spadano, J., Coakley, E. H., Field, A. E., Colditz, G., \& Dietz, W. H. (1999). The disease burden with overweight and obesity. Journal of American Medical Association, 282(16), 1523-1532. doi: 10.1001/jama.282.16.1523

Pai, M. K. (2011). Comparative study of nutritional status of elderly population living in the home for aged vs those living in the community. Biomedical Research, 22(1), 120-126.

Perissinotto, E., Pisent, C., Sergi, G., \& Grigoletto, F. (2002). Anthropometric measurements in the elderly, age and gender differences. British Journal of Nutrition, 87(2), 177-86. doi: 10.1079/ BJN2001487

Радовановић, А., \& Игњатовић, А. (2009). Физиолошке основе тренинга силе и снаге [Physiological basis of force and strength practice]. Niš, SRB: Faculty of sport and physical education.

Reddy, K. K., \& Papa Rao A. (2010). Nutritional Status and Impaired Functional Ability Among 
the Elderly. The Open Anthropology Journal, 3, 192-199. doi: 10.2174/1874912701003030192

Rikli, R. E., \& Jones, C. J. (1999). Development and validation of a functional fitness test for community-residing older adults. Journal of Aging and Physical Activity, 17, 127-159.

Rikli, R. E., \& Jones, C. J. (2001). Senior Fitness Test Manual. Champaign, IL: Human Kinetics.

Ruchlin, H. S., \& Lachs, M. S. (1999). Prevalence and correlates of exercise among older adults. Journal of Applied Gerontology, 18, 341-357. doi: 10.1177/073346489901800305

Sánchez García, S., García Peña, C., Duque López, M. X., Juárez-Cedillo, T., Cortés-Núñez, A. R., \& Reyes-Beaman, S. (2007). Anthropometric measures and nutritional status in a healthy elderly population. BMC Public Health, 7, 2. doi: 10.1186/1471-2458-7-2; PMid: 17201919; PMCid: 1769489

Setiati, S., Istanti, R., Andayani, R., Kuswardhani, R.A., Aryana, I.G., Putu, I.D., ... S. Mustika. (2010). Cut-off of anthropometry measurement and nutritional status among elderly outpatient in Indonesia, multi-centre study. Acta Medica Indonesiana, 42(4), 224-254. PMid: 21063044

Shephard, J. (1997). Aging, physical activity and health. Champaign, IL: Human Kinetics.

Spirdusso, W. W. (1995). Physical dimension of aging. Champaign, IL: Human Kinetics.
Toraman, N., Ayceman, N., \& Yaman, H. (2005). Effects of six weeks of detraining on retention of functional fitness of old people after nine weeks of multicomponent training. British Journal of Sports Medicine, 39(8), 565-568. doi: 10.1136/bjsm.2004.015586; PMid: 16046345; PMCid: 1725289

Trost, S. G., Owen, N., Bauman, A. E., Sallis, J. F., \& Brown, W. (2002). Correlates of adults 'participation in physical activity: review and update. Medicine \& Science in Sports \& Exercise, 34, 1996-2001. doi: 10.1097/00005768200212000-00020

Visser, M., Pahor, M., Tylavsky, F., Kritchevsky, S. B., Cauley, J. A., Newman, A., \& T. B. Harris. (2003). One- and two-year change in body composition as measured by DXA in a population-based cohort of older men and women. Journal of Applied Physiology, 94(6), 2368-2374. PMid: 12598481

Walsh, J. M. E., Pressman, A. R., Cauley, J. A., \& Browner, W. S. (2001). Predictors of physical activity in community-dwelling elderly white women. The Journal of General Internal Medicine, 16, 721-727. doi: 10.1111/j.1525-1497. 2001.00506.x; PMid: 11722684; PMCid:1495288

Weiner J., \& Lourie E. (1969). Human Biology: A Guide to Field Metods, International Biological programme. Oxford - Edinburgh, Great Britain: Blackwell Scientific Publications.

Received: Februar 2, 2012 Revision received: April 4, 2012 Accepted: May 1, 2012

Correspodence to: Saša Pantelić, MSc

Faculty of Sport and Physical Education Čarnojevićeva 10a 18000 Niš Srbija E-mail: spantelic2002@yahoo.com Phone: 00381641365229 